\title{
Miskonsepsi Asam Basa Berbasis Multipel Representasi pada Lintas Jenjang Pendidikan
}

\author{
Isnaini Yunitasari ${ }^{1}$, Hayuni Retno Widarti ${ }^{1}$, Nazriati ${ }^{1}$ \\ ${ }^{1}$ Pendidikan Kimia-Universitas Negeri Malang
}

\begin{tabular}{l} 
INFO ARTIKEL \\
\hline Riwayat Artikel: \\
Diterima: $11-07-2019$ \\
Disetujui: $13-12-2019$ \\
\hline
\end{tabular}

Kata kunci:

misconception;

acid base;

educational levels;

multiple representations;

miskonsepsi;

asam basa;

lintas jenjang pendidikan;

multipel representasi

\author{
Alamat Korespondensi: \\ Isnaini Yunitasari \\ Pendidikan Kimia \\ Universitas Negeri Malang \\ Jalan Semarang 5 Malang \\ E-mail: isnaini2606@gmail.com
}

\begin{abstract}
ABSTRAK
Abstract: This study aims to describe acid-base misconceptions across levels of education using multiple representation based diagnostic tests. The research method is quantitative descriptive. Analysis process of misconceptions using modified CRI. The validity of diagnostic tests is between 0.197 to 0.798 , and reliability is 0.753 and 0.626 . The research subjects were 224 people consisting of class XI students, class XII students, second semester students, and $4^{\text {th }}$ semester students. The results showed that the average percentage of acid-base misconceptions in class XI students to 4th semester students respectively was $50.30 \% ; 56.84 \% ; 53.81 \%$; and $41.07 \%$. Misconceptions that often occur in students and students related submicroscopic representations.

Abstrak: Penelitian ini bertujuan untuk mendeskripsikan miskonsepsi asam basa pada lintas jenjang pendidikan menggunakan tes diagnostik berbasis multipel representasi. Metode penelitian adalah deskriptif kuantitatif. Cara analisis miskonsepsi menggunakan CRI termodifikasi. Validitas tes diagnostik antara 0,197 hingga 0,798 , dan reliabilitas sebesar 0,753 dan 0,626. Subjek penelitian sebanyak 224 orang yang terdiri dari siswa kelas XI, siswa kelas XII, mahasiswa semester II, dan IV. Hasil penelitian menunjukkan rata-rata persentase miskonsepsi asam basa pada siswa kelas XI hingga mahasiswa semester IV secara berurutan adalah 50,30\%; 56,84\%; 53,81\%; 41,07\%. Miskonsepsi yang sering terjadi pada siswa dan mahasiswa terkait representasi submikroskopik.
\end{abstract}

Asam basa merupakan salah satu konsep kimia dasar yang kompleks karena digunakan untuk memahami konsep kimia dasar yang lain, seperti titrasi asam basa, hidrolisis, dan larutan penyangga (Demircioğlu, Ayas, and Demircioğlu 2005). Konsep asam basa juga digunakan untuk memahami konsep kimia yang lebih kompleks, seperti kimia organik (Bretz and McClary 2015)dan kimia anorganik (Wan 2014). Konsep yang dipelajari dalam asam basa tidak hanya terbatas pada konsep yang dapat teramati dengan jelas, namun mempelajari konsep yang abstrak, yaitu konsep yang tidak dapat diindera langsung oleh manusia (Amry and Rahayu 2017). (Muchtar \& Herizal 2012) menyatakan bahwa untuk memahami konsep kimia, termasuk konsep asam basa secara benar, mendalam, dan komprehensif, maka harus memahami multipel representasi dengan benar. Pemahaman seseorang terhadap kimia, khususnya konsep asam basa ditentukan oleh kemampuannya dalam memahami, mentransfer, dan menghubungkan antar fenomena dalam multipel representasi (Sunyono 2015).

Multipel representasi adalah gambaran yang menjelaskan tentang fenomena dan konsep kimia (Head et al. 2017). Multipel representai terdiri dari makroskopik, submiroskopik, dan simbolik. Makroskopik menggambarkan fenomena nyata yang dapat diindera manusia (Gkitzia, Salta, and Tzougraki 2011), melalui penglihatan, penciuman, dan sentuhan (Li and Arshad 2014; Lin, Son, and Rudd 2016; Nyachwaya and Wood 2014; Pan and Henriques 2015). Submikroskopik menjelaskan fenomena kimia pada tingkat partikulat yang tidak dapat diindera manusia, seperti atom, molekul, dan ion (Chandrasegaran, A.L., Treagust, D.F., \& Mocerino 2007; Head et al. 2017; Lin et al. 2016; Nyachwaya and Wood 2014). Simbolik menjelaskan fenomena kimia dengan menggunakan simbol, angka, huruf, ataupun tanda (Chandrasegaran, Treagust, \& Mocerino 2007; Lin et al. 2016; Nyachwaya and Wood 2014). Memahami konsep asam basa jika tidak dihubungkan dengan multipel representasi dengan benar, maka kemungkinan besar akan menimbulkan miskonsepsi (Gkitzia et al. 2011; Muchtar \& Herizal 2012).

Miskonsepsi merupakan konsepsi yang bertentangan dengan konsep-konsep ilmiah yang relevan (Hoe and Subramaniam 2016; Muchtar \& Herizal 2012) dan disepakati oleh para ahli (McClary and Bretz 2012). (Luxford and Bretz 2014) menyatakan bahwa miskonsepsi merupakan ide, gagasan, atau pikiran yang tidak didasarkan pada pemahaman ilmiah. Siswa menengah atas dan mahasiswa seharusnya sudah tidak mengalami miskonsepsi karena mereka sudah melampauhi tahap operasional formal menurut teori Perkembangan Kognitif Piaget. Seseorang yang telah melampauhi tahap operasional formal, maka sudah mampu berpikir abstrak, bernalar secara logis, serta mampu memahami bentuk-bentuk argumen (Ibda, 2015). Pada 
kenyataannya masih banyak ditemukan siswa menengah atas dan mahasiswa yang mengalami miskonsepsi pada konsep asam basa. (Hoe and Subramaniam 2016; Muchtar \& Herizal 2012) menyatakan pada penelitiannya bahwa siswa menengah atas menganggap asam merupakan senyawa yang mengandung atom $\mathrm{H}$ dan basa mengandung atom $\mathrm{OH}$ pada rumus strukturnya. (Artdej et al. 2010; Yalçin 2011) dalam hasil penelitiannya menunjukkan bahwa mahasiswa menganggap semakin besar konsentrasi maka kekuatan asam semakin meningkat. Hasil penelitian (Pinarbasi 2007; Yalçin 2011) menunjukkan bahwa siswa menengah atas dan mahasiswa menganggap reaksi asam dengan basa yang molnya sama menghasilkan garam bersifat netral. Menurut (Suwarto 2013) bahwa siswa dan mahasiswa yang mengalami miskonsepsi cenderung menurun dengan bertambahnya umur mereka dan semakin tinggi tingkat pendidikan mereka.

Tes diagnostik untuk menganalisis miskonsepsi pada penelitian-penelitian sebelumnya cenderung hanya melibatkan representasi simbolik saja. Hal ini menunjukkan bahwa masing-masing level dalam multipel representasi tidak digunakan secara seimbang dalam menyusun tes diagnostik untuk menganalisis miskonsepsi asam basa. Pemahaman asam basa yang ingin dianalisis tidak dihubungkan dengan pemahaman multipel representasi. Kemampuan menghubungkan informasi dan ide pada multipel representasi untuk suatu konsep lebih bermakna dibandingkan pemahaman notasi simbolik saja (Lin et al. 2016). Cara menganalisis miskonsepsi asam basa pada penelitian ini menggunakan teknik CRI yang dikembangkan (Hasan, Bagayoko, and Kelley 1999) dan dimodifikasi oleh (Potgieter, Rogan, and Howie 2005) dan (Hakim, Liliasari, and Kadarohman 2012).

CRI termodifikasi dapat menganalisis miskonsepsi, dapat membedakan siswa dan mahasiswa yang paham konsep, miskonsepsi, dan tidak paham konsep dengan baik sesuai dengan karakter siswa dan mahasiswa Indonesia yang kurang percaya diri dalam memberikan jawaban (Hakim et al. 2012). Teknik CRI termodifikasi sudah dilakukan oleh peneliti-peneliti lain, salah satunya oleh (Widarti, Permanasari, and Mulyani 2017) yang mengidentifikasi miskonsepsi pada konsep titrasi asam basa dan titrasi argentometri. Hasil penelitian (Widarti et al. 2017) menunjukkan bahwa rata-rata miskonsepsi yang terdeteksi sebesar 28,6\%. Setelah tes diagnostik juga dilakukan wawancara semi terstruktur agar diperoleh informasi miskonsepsi asam basa yang dialami oleh siswa dan mahasiswa secara lebih lengkap. Pada penelitian ini, menganalisis miskonsepsi asam basa pada siswa menengah atas dan mahasiswa menggunakan tes diagnostik berbasis multipel representasi, dan cara menganalisis miskonsepsinya menggunakan CRI termodifikasi. Hal ini dilakukan agar diperoleh miskonsepsi asam basa pada siswa dan mahasiswa yang lebih lengkap dan mendalam. Tujuan penelitian ini adalah untuk mendeskripsikan miskonsepsi asam basa pada lintas jenjang pendidikan menggunakan tes diagnostik berbasis multipel representasi.

\section{METODE}

Penelitian ini menggunakan metode deskriptif kuantitatif. Kuantitatif digunakan untuk menghitung persentase miskonsepsi siswa dan mahasiswa pada konsep asam basa, sedangkan deskriptif untuk mendeskripsikan miskonsepsi asam basa apa saja yang dialami oleh siswa dan mahasiswa. Subjek penelitian terdiri dari 88 siswa menengah atas kelas XI IPA, 38 siswa menengah atas kelas XII IPA, 42 mahasiswa semester II Jurusan Kimia, dan 56 mahasiswa semester IV Jurusan Kimia. Siswa menengah atas kelas XI berasal dari SMAN 8 dan SMAN 9 Malang, siswa menengah atas kelas XII berasal dari SMAN 9 Malang, sedangkan mahasiswa semester II dan IV berasal dari Universitas Negeri Malang. Semua subjek penelitian sedang menempuh pembelajaran pada semester genap tahun ajaran 2018/2019. Semua subjek penelitian telah mempelajari konsep asam basa. Siswa menengah atas kelas XI dan kelas XII mempelajari konsep asam basa pada kelas XI semester II. Mahasiswa semester II dan IV mempelajari konsep asam basa pada kelas XI semester II dan pada saat kuliah semester II. Konsep asam basa terdiri dari sub-konsep asam basa menurut Arrhenius, asam basa menurut Bronsted-Lowry, asam basa menurut Lewis, kekuatan asam dan kekuatan basa, reaksi asam dan basa, serta $\mathrm{pH}$ asam dan $\mathrm{pH}$ basa.

Instrumen tes yang digunakan adalah tes diagnostik berbasis multipel representasi dengan teknik CRI termodifikasi, dan pedoman wawancara. Tes diagnostik terdiri dari soal pilihan ganda, alasan terbuka, dan tingkat keyakinan. Tes diagnostik yang digunakan untuk siswa dan mahasiswa hampir sama, 30 soal yang sama digunakan untuk siswa dan mahasiswa, kemudian dua soal tambahan untuk hanya mahasiswa. Soal tambahan untuk mahasiswa terkait sub-konsep kekuatan asam dan kekuatan basa, karena kedalaman konsepnya berbeda. Soal tes diagnostik telah divalidasi oleh lima ahli kimia, yaitu dua dosen kimia Universitas Negeri Malang, dua guru kimia SMAN 8 Malang, dan satu guru kimia SMAN 9 Malang. Semua soal tes diagnostik valid dan reliabel. Validitas dihitung menggunakan Pearson Correlation Product Momen dan reliabilitas dihitung menggunakan Cronbac's Alpha. Soal yang sama untuk siswa dan mahasiswa memiliki validitas sebesar 0,197-0,582, dan reliabilitas sebesar 0,753. Soal tambahan untuk mahasiswa memiliki validitas sebesar 0,719-0,798, dan reliabilitas sebesar 0,626. Setelah dilakukan tes diagnostik, dilaksanakan wawancara semi terstruktur. Pedoman wawancara yang digunakan untuk mengkonfirmasi jawaban dan menggali lebih dalam miskonsepsi siswa dan mahasiswa telah dikonsultasikan kepada dosen pembimbing. Banyaknya subjek penelitian yang diwawancara adalah situasional. Pertanyaan yang diajukan terdiri dari pertanyaan yang menggali pemahaman konsep asam basa dan pertanyaan yang sesuai dengan pola jawaban siswa dan mahasiswa saat tes diagnostik.

Miskonsepsi asam basa pada siswa dan mahasiswa dianalisis menggunakan teknik CRI yang dikembangkan oleh (Hasan et al. 1999) dan dimodifikasi oleh (Potgieter et al. 2005) dan (Hakim et al. 2012). Skala CRI yang digunakan meliputi 1 = menebak; 2 = kurang yakin; 3 = yakin; 4 = sangat yakin. Kategori pemahaman siswa dan mahasiswa berdasarkan variasi jawaban dapat ditunjukkan pada tabel 1. Hasil tes diagnostik asam basa siswa dan mahasiswa pada setiap item soal diberi kodekode sesuai tabel 1, kemudian dilakukan perhitungan persentase rata-rata siswa dan mahasiswa yang mengalami miskonsepsi dengan kode M3, M5, dan M7 pada setiap item soal. Jenis-jenis miskonsepsi pada setiap item soal yang memiliki persentase 
minimal 20\%, dilakukan analisis dan dideskripsikan, dan didukung dengan hasil wawancara. Menurut (Dhindsa and Treagust 2012) bahwa dikatakan terjadi miskonsepsi jika persentase siswa dan mahasiswa dalam menjawab soal tes diagnostik lebih atau sama dengan $20 \%$.

Tabel 1. Kategori Pemahaman Siswa dan Mahasiswa berdasarkan Variasi Jawaban

\begin{tabular}{|c|c|c|c|c|c|}
\hline No & Jawaban & Alasan & CRI & $\begin{array}{r}\text { Kategori } \\
\end{array}$ & Kode \\
\hline 1 & Benar & Benar & $>2,5$ & Memahami konsep dengan baik & P1 \\
\hline 2 & Benar & Benar & $<2,5$ & $\begin{array}{l}\text { Memahami konsep tetapi tidak yakin dengan jawaban } \\
\text { yang diberikan }\end{array}$ & $\mathrm{P} 2$ \\
\hline 3 & Benar & Salah & $>2,5$ & Miskonsepsi & M3 \\
\hline 4 & Benar & Salah & $<2,5$ & Tidak paham konsep & TP4 \\
\hline 5 & Salah & Benar & $>2,5$ & Miskonsepsi & M5 \\
\hline 6 & Salah & Benar & $<2,5$ & Tidak paham konsep & TP6 \\
\hline 7 & Salah & Salah & $>2,5$ & Miskonsepsi & M7 \\
\hline 8 & Salah & Salah & $<2,5$ & Tidak paham konsep & TP8 \\
\hline
\end{tabular}

\section{HASIL}

Hasil analisis miskonsepsi menunjukkan bahwa siswa menengah astas kelas XI, siswa menengah atas kelas XII, mahasiswa semester II, dan IV mengalami miskonsepsi asam basa. Persentase rata-rata miskonsepsi lintas jenjang pendidikan pada setiap sub-konsep asam basa secara rinci dapat ditunjukkan pada tabel 2.

Tabel 2. Persentase Rata-rata Miskonsepsi Lintas Jenjang Pendidikan pada Setiap Sub-Konsep Asam Basa

\begin{tabular}{|c|c|c|c|c|c|c|c|c|c|c|c|c|}
\hline \multirow{3}{*}{$\begin{array}{c}\% \\
\text { Miskonsepsi pada Setiap } \\
\text { Sub-Konsep }\end{array}$} & \multicolumn{12}{|c|}{ Jenjang Pendidikan } \\
\hline & \multicolumn{3}{|c|}{ Siswa Kelas XI } & \multicolumn{3}{|c|}{ Siswa Kelas XII } & \multicolumn{3}{|c|}{ Mahasiswa Semester II } & \multicolumn{3}{|c|}{ Mahasiswa Semester IV } \\
\hline & M3 & M5 & M7 & M3 & M5 & M7 & M3 & M5 & M7 & M3 & M5 & M7 \\
\hline Asam Basa Arrhenius & 16,59 & 4,77 & 29,55 & 16,83 & 0,00 & 32,63 & 21,43 & 1,43 & 12,86 & 22,14 & 1,07 & 13,21 \\
\hline Asam Basa Bronsted-Lowry & 21,36 & 1,14 & 16,36 & 25,79 & 0,00 & 27,89 & 20,48 & 0,00 & 18,57 & 18,57 & 3,21 & 12,86 \\
\hline Asam Basa Lewis & 36,82 & 0,23 & 21,36 & 26,84 & 0,00 & 37,37 & 20,00 & 1,90 & 18,10 & 17,86 & 1,07 & 17,86 \\
\hline $\begin{array}{l}\text { Kekuatan Asam dan } \\
\text { Kekuatan Basa }\end{array}$ & 6,82 & 0,23 & 47,50 & 8,95 & 0,00 & 32,11 & 13,95 & 1,36 & 46,94 & 14,80 & 0,26 & 36,99 \\
\hline \multirow{2}{*}{$\begin{array}{l}\text { Reaksi Asam dan Basa } \\
\text { pH Asam dan } \\
\text { pH Basa }\end{array}$} & 20,23 & 0,00 & 23,41 & 6,32 & 0,00 & \multirow{2}{*}{$\begin{array}{l}57,89 \\
67,37\end{array}$} & 12,86 & 0,48 & 26,19 & 12,50 & 0,00 & 21,07 \\
\hline & 12,27 & 0,00 & 43,18 & 1,05 & 0,00 & & 8,57 & 0,95 & 53,81 & 9,64 & 0,36 & 38,57 \\
\hline Rata-Rata & \multicolumn{3}{|c|}{$\mathbf{5 0 , 3 0}$} & \multicolumn{3}{|c|}{56,84} & \multicolumn{3}{|c|}{47,62} & \multicolumn{3}{|c|}{41,07} \\
\hline
\end{tabular}

Tabel 2 menunjukkan persentase rata-rata miskonsepsi asam basa yang dialami oleh siswa menengah atas kelas XI sebesar 50,30\%, siswa menengah atas kelas XII sebesar 56,84\%, mahasiswa semester II sebesar 47,62\%, dan mahasiswa semester IV sebesar 41,07\%. Semakin tinggi jenjang pendidikannya, miskonsepsi yang dialami semakin menurun, kecuali pada kelas XII.

\section{PEMBAHASAN}

Siswa menengah atas dan mahasiswa seharusnya sudah tidak mengalami miskonsepsi karena telah melampauhi tahap operasional formal, sehingga sudah mampu berpikir abstrak, bernalar secara logis, serta mampu memahami bentuk-bentuk argumen (Ibda 2015). Pada kenyataannya, siswa menengah atas dan mahasiswa masih banyak yang mengalami miskonsepsi. Hal ini dikarenakan miskonsepsi resisten terhadap perubahan. (Ozmen 2004) menyatakan bahwa miskonsepsi resisten terhadap upaya untuk diubah dari waktu ke waktu, meskipun tingkat pendidikan kimianya meningkat. Ciri-ciri miskonsepsi adalah tahan lama dan tertanam kuat dalam pikiran seseorang (Luoga, Ndunguru, and Mkoma 2013). Hasil penelitian menunjukkan persentase miskonsepsi asam basa dari jenjang pendidikan yang rendah ke jenjang pendidikan yang tinggi mengalami penurunan, kecuali pada siswa kelas XI ke kelas XII mengalami kenaikan.

Hasil penelitian ini tidak sesuai dengan pernyataan (Suwarto 2013) bahwa jumlah siswa yang mengalami miskonsepsi cenderung menurun dengan bertambahnya umur mereka dan semakin tinggi tingkat pendidikan mereka. Hal ini kemungkinan disebabkan oleh beberapa faktor. Faktor pertama, siswa dan mahasiswa umumnya belajar konsep asam basa dengan cara menghafal. Nakhleh dalam (Nyachwaya and Wood 2014) menyatakan bahwa menghafal mengganggu pemahaman konseptual. Banyak miskonsepsi yang terjadi ketika siswa dan mahasiswa menghafal aturan, prinsip, maupun konsep (Romine, Todd, and Clark 2016). Faktor kedua, jangka waktu siswa kelas XII mempelajari konsep asam basa dengan melaksanakan tes diagnostik asam basa cukup lama. Siswa kelas XII mempelajari konsep asam basa hanya pada saat mereka kelas XI semester genap. Faktor 
ketiga adalah berdasarkan hasil wawancara siswa kelas XII, mereka menyatakan bahwa mereka hanya fokus belajar pada mata pelajaran IPA yang akan diujikan dalam Ujian Nasional. Pada umumnya, siswa tidak memilih kimia sebagai mata pelajaran IPA yang akan diujikan dalam Ujian Nasional, sehingga mereka tidak belajar kimia dengan tekun. Miskonsepsi pada setiap subkonsep asam basa yang dialami oleh siswa menengah atas kelas XI, siswa menengah atas kelas XII, mahasiswa semester II, dan semester IV dapat dideskripsikan sebagai berikut.

\section{Asam Basa menurut Arrhenius}

Miskonsepsi pada sub-konsep asam basa menurut Arrhenius yang dialami siswa dan mahasiswa ada lima. Miskonsepsi pertama terjadi pada soal nomor 1 , dengan kode M3, dan hanya dialami oleh siswa kelas XI. Siswa menganggap bahwa $\mathrm{NH}_{3}$ merupakan basa menurut Arrhenius karena dapat menerima proton (ion $\mathrm{H}^{+}$) ketika dilarutkan dalam air. Miskonsepsi ini sama dengan hasil penelitian yang ditemukan oleh (Artdej et al. 2010). Siswa menjawab benar bahwa $\mathrm{NH}_{3}$ merupakan basa lemah yang terurai sebagian menghasilkan $\mathrm{NH}_{4}{ }^{+}$dan $\mathrm{OH}^{-}$secara submikroskopik, dan pada persamaan reaksinya memiliki panah kesetimbangan, namun konsep asam basa Arrheniusnya salah. Miskonsepsi ini kemungkinan disebabkan siswa memahami konsep asam basa secara hafalan, sehingga pemahaman konsep asam basa menurut Arrhenius terbalik dengan pemahaman konsep asam basa menurut Bronsted-Lowry.

Miskonsepsi kedua terjadi pada siswa kelas XI, siswa kelas XII, dan mahasiswa semester IV dengan kode M7. Siswa dan mahasiswa menganggap bahwa penulisan tanda panah pada persamaan reaksi asam basa menurut Arrhenius selalu satu arah. Pada soal nomor 1, sebagian siswa kelas XI menganggap bahwa $\mathrm{NH}_{3}$ merupakan asam menurut Arrhenius, dan sebagian lagi menganggap bahwa $\mathrm{NH}_{3}$ merupakan basa Arrhenius, namun penulisan panah pada persamaan reaksinya harus satu arah. Pada soal nomor 2, siswa kelas XI, siswa kelas XII, dan mahasiswa semester IV menganggap bahwa HCOOH merupakan asam menurut Arrhenius, namun penulisan arah panahnya pada persamaan reaksi harus satu arah, tidak kesetimbangan walaupun asam dan basa lemah. Miskonsepsi ini juga kemungkinan disebabkan karena siswa dan mahasiswa menghafal.

Miskonsepsi ketiga terjadi pada siswa kelas XI, siswa kelas XII, dan mahasiswa semester II. Pada soal nomor 1, siswa kelas XI dan siswa kelas XII menganggap bahwa $\mathrm{NH}_{3}$ merupakan asam menurut Arrhenius karena terdapat atom $\mathrm{H}$ pada rumus molekulnya. Pada soal nomor 3, siswa kelas XI, siswa kelas XII, dan mahasiswa semester II menganggap bahwa HCN merupakan asam menurut Arrhenius karena mengandung atom $\mathrm{H}$ pada rumus molekulnya. Pada soal nomor 5, siswa kelas XII menganggap bahwa $\mathrm{N}_{2} \mathrm{H}_{4}$ termasuk asam menurut Arrhenius karena pada rumus molekulnya ada atom $\mathrm{H}$. Apabila pada rumus molekulnya terdapat atom $\mathrm{H}$, maka dalam air dapat melepaskan ion $\mathrm{H}^{+}$sehingga disebut dengan asam. Miskonsepsi ini sama dengan hasil penelitian yang dilakukan oleh (Hoe and Subramaniam 2016; Muchtar \& Herizal 2012; Yalçin 2011)yang menyatakan bahwa asam menurut Arrhenius adalah senyawa yang mengandung atom $\mathrm{H}$ pada rumus kimianya, sehingga menghasilkan ion $\mathrm{H}^{+}$. Soal nomor 1 dan 5 termasuk miskonsepsi dengan kode M7, sedangkan nomor 3 termasuk miskonsepsi dengan kode M3. Miskonsepsi ini kemungknan dikarenakan penyederhanaan konsep sehingga siswa dan mahasiswa lebih mudah memahami dan menghafal. Penyederhanaan konsep dapat menimbulkan miskonsepsi (Jannah, Ningsih, and Ratman 2017; Sugiyarto; Al 2013). Menghafal aturan, prinsip, dan konsep maka akan menyebabkan terjadinya miskonsepsi (Romine et al. 2016).

Miskonsepsi keempat dan kelima dialami oleh siswa kelas XI saja. Miskonsepsi keempat adalah siswa menganggap bahwa $\mathrm{HCOOH}$ merupakan asam menurut Arrhenius yang dapat melepaskan $\mathrm{H}^{+}$dalam air, namun $\mathrm{H}^{+}$yang lepas adalah atom $\mathrm{H}$ yang bagian depan. Siswa menyatakan dalam wawancara bahwa karena urutannya $\mathrm{HCOOH}$, maka atom $\mathrm{H}$ yang lepas adalah yang di depan. Miskonsepsi ini terjadi pada nomor 2 dengan kode M7. Miskonsepsi kelima yaitu siswa menganggap bahwa asam kuat mengalami ionisasi sempurna, namun gambaran submikroskopik larutan asam kuat terdiri dari molekul-molekul asam, bukan ion $\mathrm{H}^{+}$dan anion asam. Miskonsepsi ini terjadi pada soal nomor 4 dengan kode $\mathrm{M}_{5}$. $\mathrm{HNO}_{3}$ menurut Arrhenius adalah asam yang dapat melepas $\mathrm{H}^{+}$, dan $\mathrm{HNO}_{3}$ merupakan asam kuat yang terionisasi sempurna. Berdasarkan hasil wawancara, siswa berpendapat bahwa asam kuat terionisasi sempurna, gambaran submikroskopiknya berupa molekul-molekul asam. Gambaran submikroskopik yang terdiri dari ion-ion menunjukkan bahwa tidak terionisasi, sedangkan gambaran submikroskopik yang terdiri dari ion dan molekul termasuk terionisasi sebagian.

\section{Asam Basa menurut Bronsted-Lowry}

Miskonsepsi pada sub-konsep asam basa menurut Bronsted-Lowry yang dialami siswa dan mahasiswa ada tiga. Miskonsepsi pertama hanya dialami oleh siswa SMA kelas XII yang terjadi pada soal nomor 6 dan 8 dengan kode M7. Siswa mengaggap bahwa asam menurut Bronsted-Lowry adalah menerima proton, sedangkan basa mendonorkan proton. Pada reaksi antara $\mathrm{HCO}_{3}{ }^{-}$dengan $\mathrm{H}_{2} \mathrm{O}$, siswa berpendapat bahwa ion $\mathrm{HCO}_{3}{ }^{-}$berperan sebagai asam Bronsted-Lowry karena menerima proton, sedangkan $\mathrm{HCO}_{3}{ }^{-}$sebagai basa karena mendonorkan proton. Miskonsepsi ini sesuai hasil penelitian (Artdej et al. 2010) yang menyatakan bahwa asam Bronsted-Lowry adalah akseptor proton, sedangkan basa Bronsted-Lowry adalah donor proton. Miskonsepsi ini mungkin disebabkan siswa menghafal konsep, sehingga dapat menimbulkan miskonsepsi. Miskonsepsi kedua juga hanya dialami oleh siswa kelas XII. Miskonsepsi ini terjadi pada soal nomor 7, 8, 10 dengan kode M3. Siswa menganggap bahwa asam Bronsted-Lowry merupakan spesi yang mendonor proton ke basa konjugat, sedangkan basa Bronsted-Lowry merupakan spesi yang menerima proton dari asam konjugat. 
Miskonsepsi ketiga terjadi pada siswa kelas XI, mahasiswa semester II, dan semester IV. Miskonsepsi ini terjadi pada soal nomor 9 dengan kode M7. Siswa dan mahasiswa menganggap bahwa dalam larutan asam fosfat, hanya molekul $\mathrm{H}_{3} \mathrm{PO}_{4}$ saja yang bertindak sebagai asam karena kaya akan proton. Molekul $\mathrm{H}_{3} \mathrm{PO}_{4}$ menurut siswa dan mahasiswa mengalami ionisasi satu kali. Miskonsepsi ini kemungkinan disebabkan siswa dan mahasiswa tidak memperhatikan gambaran submikroskopik larutan asam fosfat pada soal yang menunjukkan bahwa asam fosfat terprotonasi tiga kali. Contoh hasil wawancara dapat ditunjukkan sebagai berikut.

\section{Asam Basa menurut Lewis}

Miskonsepsi pada sub-konsep asam basa menurut Lewis yang dialami siswa dan mahasiswa ada empat. Miskonsepsi pertama adalah siswa menganggap bahwa asam Lewis adalah spesi yang tidak memiliki PEB, sedangkan basa Lewis merupakan spesi yang memiliki PEB. Miskonsepsi ini dialami oleh siswa kelas XI pada soal nomor 11, 13, 14, dan 15 dengan kode M3. Siswa kelas XII mengalami miskonsepsi ini pada soal nomor 13 dan 14 dengan kode M3. Miskonsepsi ini disebabkan dari siswa menyederhanakan konsep dan menghafal konsep. Siswa menyederhanakan konsep asam basa Lewis bahwa molekul yang memiliki pasangan elektron bebas pasti basa, sedangkan molekul yang tidak memiliki pasangan elektron bebas pasti asam. Penyederhanaan konsep tersebut kemudian dihafalkan, sehingga ketika ditanya mengenai konsep asam basa Lewis yang benar, siswa mengalami miskonsepsi.

Miskonsepsi kedua dialami oleh siswa kelas XI, kelas XII, dan mahasiswa semester II pada soal nomor 12 dengan kode M7. Siswa dan mahasiswa menganggap bahwa pada reaksi antara $\mathrm{Cu}^{2+}$ dengan $\mathrm{NH}_{3}$ menghasilkan $\left[\mathrm{Cu}\left(\mathrm{NH}_{3}\right)_{4}\right]^{2+}$, ion $\mathrm{Cu}^{2+}$ bertindak sebagai asam dan $\mathrm{NH}_{3}$ sebagai basa. Pernyataan ini sudah benar, namun persamaan reaksi yang dipilih salah. Siswa dan mahasiswa menganggap bahwa jumlah molekul $\mathrm{NH}_{3}$ yang dibutuhkan untuk berikatan dengan ion $\mathrm{Cu}^{2+}$ hanya satu, karena $\mathrm{Cu}^{2+}$ melepaskan 2 elektron dan setiap molekul $\mathrm{NH}_{3}$ memiliki 2 elektron bebas. Miskonsepsi ini kemungkinan disebabkan siswa dan mahasiswa tidak memperhatikan keterangan pada soal mengenai hasil reaksi yang terbentuk.

Miskonsepsi ketiga terjadi pada soal nomor 11 dengan kode M7, dan hanya dialami siswa kelas XII. Siswa menganggap bahwa $\mathrm{BH}_{3}$ merupakan basa Lewis karena rumus molekulnya mirip dengan $\mathrm{NH}_{3} . \mathrm{NH}_{3}$ termasuk basa Lewis karena dapat mendonorkan pasangan elektron bebas. Miskonsepsi ini sama dengan hasil penelitian yang ditemukan oleh (Artdej et al. 2010) bahwa siswa menganggap $\mathrm{BH}_{3}$ merupakan basa Lewis karena struktur molekulnya mirip dengan $\mathrm{NH}_{3}$. Miskonsepsi keempat juga terjadi pada siswa kelas XI saja dengan kode M7. Miskonsepsi ini terjadi pada soal nomor 15. Siswa menganggap bahwa asam Lewis adalah spesi yang donor pasangan elektron bebas, sedangkan basa Lewis merupakan akseptor pasangan elektron bebas. Miskonsepsi ini terjadi kemungkinan siswa menghafal konsep sehingga konsep yang dimiliki terbalik.

\section{Kekuatan Asam dan Kekuatan Basa}

Miskonsepsi pada sub-konsep kekuatan asam dan kekuatan basa yang dialami siswa dan mahasiswa ada lima. Miskonsepsi pertama dialami oleh semua jenjang pendidikan dengan kode M7. Siswa kelas XI, mahasiswa semester II, dan mahasiswa semester IV mengalami miskonsepsi pada soal nomor 16 dan 19, sedangkan siswa kelas XII mengalami miskonsepsi ini hanya pada soal nomor 19. Siswa dan mahasiswa menganggap bahwa semakin besar konsentrasi asam dan basa, maka kekuatan asam dan kekuatan basa juga semakin besar. Miskonsepsi ini sama seperti hasil penelitian yang ditemukan (Demircioğlu et al. 2005; Hoe and Subramaniam 2016; Yalçin 2011) yang menyatakan asam dan basa yang lebih pekat memiliki kekuatan asam dan kekuatan basa yang lebih besar, sedangkan (Artdej et al. 2010; Tümay 2016) menyatakan bahwa kekuatan asam meningkat jika konsentrasi ion $\mathrm{H}^{+}$dari hasil ionisasi juga meningkat.

Miskonsepsi kedua hanya siswa kelas XII pada soal nomor 19 dengan kode M7. Siswa menganggap bahwa semakin kecil konsentrasi asam, maka kekuatan asamnya semakin besar karena pH semakin besar. Miskonsepsi ini sama seperti yang diperoleh dari penelitian (Cetingul, Ipek; geban 2011) yang menyatakan bahwa asam kuat selalu memiliki pH lebih tinggi dari asam lemah. Miskonsepsi ketiga adalah semakin sedikit jumlah atom $\mathrm{H}$ pada rumus molekul asam yang terprotonasi, maka kekuatan asamnya semakin besar. Siswa menganggap kekuatan $\mathrm{HIO}_{3}$ lebih kuat dari $\mathrm{H}_{2} \mathrm{SeO}_{4}$ karena $\mathrm{HIO}_{3}$ terprotonasi satu kali dan $\mathrm{H}_{2} \mathrm{SeO}_{4}$ terprotonasi dua kali. Miskonsepsi ini dialami oleh siswa kelas XI dan siswa kelas XII, dan mahasiswa semester II pada soal nomor 20 dengan kode M7.

Miskonsepsi keempat terjadi pada soal nomor 31 yang merupakan soal tambahan untuk mahasiswa. Miskonsepsi ini dialami mahasiswa semester II dan mahasiswa semester IV dengan kode M3. Mahasiswa menganggap bahwa semakin banyak atom oksigen pada senyawa $\mathrm{HClO}_{2}, \mathrm{HClO}_{3}$, dan $\mathrm{HClO}_{4}$, maka atom $\mathrm{Cl}$ semakin kuat menarik atom $\mathrm{O}$ dan atom $\mathrm{H}$ mudah lepas, sehingga kekuatan asam semakin besar. Miskonsepsi kelima hanya dialami oleh mahasiswa semester 2 pada soal nomor 32 dengan kode M7. Mahasiswa menganggap bahwa kekuatan $\mathrm{HCl}>\mathrm{HBr}>\mathrm{HI}$ karena keelektronegatifan $\mathrm{Cl}>\mathrm{Br}>\mathrm{I}$. $\mathrm{Semakin}$ besar keelektronegatifan atom $\mathrm{X}(\mathrm{Cl} / \mathrm{Br} / \mathrm{I})$, maka rapatan elektron pada atom $\mathrm{X}$ semakin rendah dan atom $\mathrm{H}$ lebih mudah lepas menjadi ion $\mathrm{H}^{+}$. Miskonsepsi ini sesuai dengan hasil penelitian yang dilakukan oleh (Tümay 2016).

\section{Reaksi Asam dan Basa}


Miskonsepsi pada sub-konsep reaksi asam dan basa yang dialami siswa dan mahasiswa ada dua. Miskonsepsi pertama dialami oleh semu jenjang pendidikan. Siswa dan mahasiswa menganggap bahwa reaksi antara asam dan basa dengan mol yang sama pasti menghasilkan garam bersifat netral. Miskonsepsi ini sesuai dengan hasil penelitian yang ditemukan oleh (Pinarbasi 2007; Sheppard 2006; Yalçin 2011) yang menyatakan bahwa reaksi antara asam dan basa dengan mol yang sama selalu menghasilkan produk garam yang bersifat netral. Miskonsepsi pada siswa kelas XI terjadi pada soal nomor 21, 23, dan 24 dengan kode M7, serta nomor 22 dengan kode M3. Miskonsepsi pada siswa kelas XII terjadi pada soal nomor 21 dengan kode M7. Miskonsepsi pada mahasiswa semester II terjadi pada soal nomor 23 dan 24 dengan kode M7. Miskonsepsi pada mahasiswa semester 4 terjadi pada soal nomor 21 dan 23 dengan kode M7.

Miskonsepsi kedua hanya dialami oleh siswa kelas XII yang terjadi pada soal nomor 22, 23, 24, dan 25 dengan kode M7. Siswa salah dalam menentukan kekuatan asam dan/atau kekuatan basa yang bereaksi sehingga siswa juga salah dalam menentukan hasil reaksi asam dan basa. Pada soal nomor 22, siswa menganggap bahwa $\mathrm{HNO}_{3}$ merupakan asam lemah, jika direaksikan dengan $\mathrm{NaOH}$ yang merupakan basa kuat, maka menghasilkan garam yang bersifat basa. Pada soal nomor 23 siswa menganggap bahwa $\mathrm{HCl}$ merupakan asam lemah, jika direaksikan dengan $\mathrm{NH}_{4} \mathrm{OH}$ yang merupakan basa kuat, maka menghasilkan campuran yang bersifat basa. Pada soal nomor 24 siswa menganggap bahwa $\mathrm{HClO}$ merupakan asam kuat, jika direaksikan dengan $\mathrm{NaOH}$ yang termasuk basa lemah, maka hasilnya adalah campuran yang bersifat asam. Pada soal nomor 25 siswa menganggap bahwa HI merupakan asam lemah jika direaksikan dengan KOH yang merupakan basa kuat, maka akan menghasilkan campuran yang bersifat basa. Hal ini dikarenakan siswa menghafal asam/basa kuat dan asam/basa lemah, tanpa memperhatikan gambaran submikroskopik atau harga $K_{\mathrm{a}}$ dan $K_{\mathrm{b}}$ yang telah diberikan pada soal. Hafalan dapat menyebabkan miskonsepsi (Romine et al, 2016).

\section{pH Asam dan pH Basa}

Miskonsepsi pada sub-konsep $\mathrm{pH}$ asam dan $\mathrm{pH}$ basa yang dialami siswa dan mahasiswa ada tiga. Miskonsepsi pertama adalah siswa dan mahasiswa pada semua jenjang pendidikan menganggap bahwa larutan asam kuat yang memiliki konsentrasi sebesar $10^{-8} \mathrm{M}$ memiliki pH 8. Larutan basa kuat dengan konsentrasi $10^{-9} \mathrm{M}$ memiliki pH 5. Miskonsepsi ini sesuai dengan temuan dari penelitian yang dilakukan oleh (Muchtar \& Herizal 2012; Pinarbasi 2007) dalam hasil penelitianya menyatakan bahwa menurut siswa pada perhitungan $\mathrm{pH}$ itu konsentrasi $\mathrm{H}^{+}$hanya berasal dari zat terlarut saja, konsentrasi $\mathrm{H}^{+}$dari air tidak diperhitungkan. Miskonsepsi ini terjadi pada soal nomor 26 dan nomor 30 dengan kode M7. Miskonsepsi ini kemungkinan disebabkan karena siswa dan mahasiswa terlalu fokus pada pemahaman algoritmik karena berhubungan dengan pH. Siswa dan mahasiswa dalam menentukan $\mathrm{pH}$ asam dan $\mathrm{pH}$ basa dengan cara memasukkan konsentrasi asam atau basa ke dalam rumus $\mathrm{pH}$.

Miskonsepsi kedua adalah semakin banyak jumlah $\mathrm{H}^{+}$yang terurai, maka $\mathrm{pH}$ asam semakin besar. Semakin banyak jumlah $\mathrm{OH}^{-}$yang terurai, maka $\mathrm{pH}$ basa semakin kecil. Miskonsepsi ini dialami oleh siswa kelas XI pada soal nomor 27 dan 28 dengan kode M7, dan mahasiswa semester IV pada soal nomor 27 dengan kode M7. Miskonsepsi ini kemungkinan disebabkan karena siswa dan mahasiswa menghafal konsep sehingga konsep yang dialami terbalik-balik dan menyebabkan miskonsepsi. Siswa dan mahasiswa yang menghafal konsep dapat menimbulkan banyak miskonsepsi (Romine et al. 2016). Miskonsepsi ketiga hanya dialami oleh siswa kelas XII pada soal nomor 29 dengan kode M7. Siswa menganggap bahwa $\mathrm{pH}$ RbOH yang termasuk basa kuat, dan $\mathrm{NH}_{4} \mathrm{OH}$ yang termasuk basa lemah adalah sama karena molnya juga sama.

Miskonsepsi asam basa yang banyak dialami siswa dan mahasiswa jika ditinjau dari multipel representasi terjadi pada soal-soal yang melibatkan gambaran submikroskopik. Hal ini karena mahasiswa dan siswa tidak memperhatikan gambaran submikroskopik pada soal dengan baik, siswa dan mahasiswa lebih melibatkan pemahaman mereka secara hafalan. Menurut (Romine et al. 2016) bahwa siswa dan mahasiswa yang memahami konsep, aturan, maupun prinsip secara hafalan, maka akan banyak menimbulkan miskonsepsi. Selain itu, siswa dan mahasiswa dalam memahami konsep menggunakan penyederhanaan konsep, tidak menggunakan pemahaman multiple representasinya, khususnya submikroskopik, sehingga siswa dan mahasiswa banyak mengalami miskonsepsi. Penyederhanaan materi dapat menyebabkan miskonsepsi (Jannah et al. 2017; Sugiyarto; Al 2013). Menurut (Sunyono 2015) bahwa pemahaman seseorang terhadap kimia ditentukan oleh kemampuannya dalam mentransfer dan menghubungkan antar fenomena-fenomena pada representasi kimia. Apabila kemampuan mengenai multipel representasi beserta hubungan ketiga level representasi rendah, maka kemungkinan besar akan menimbulkan miskonsepsi (Gkitzia et al. 2011; Muchtar \& Herizal 2012). Representasi submikroskopik penting untuk dipelajari karena representasi submikroskopik merupakan satu-satunya representasi yang dapat menggambarkan sifat partikel materi yang merupakan dasar untuk interpretasi pemahaman atau fenomena kimia (Gkitzia et al. 2011). (Hoe and Subramaniam 2016) menyatakan bahwa representasi submikroskopik sangat penting untuk memahami dan mejelaskan fenomena kimia. Jadi, multipel representasi dan hubungan antara representasi harus dipelajari dengan benar, dan harus digunakan dalam memahami konsep kimia agar dapat dimiliki pemahaman konsep kimia yang utuh dan benar. 
Berdasarkan hasil penelitian ini dapat disimpulkan bahwa siswa menengah atas kelas XI, Siswa Menengah Atas kelas XII, mahasiswa semester II, dan semester IV mengalami miskonsepsi asam dan basa. Semakin tinggi jenjang pendidikan, miskonsepsi yang dialami semakin menurun, kecuali siswa menengah atas kelas XII yang memiliki miskonsepsi asam basa paling tinggi. Miskonsepsi-miskonsepsi yang dialami siswa dan mahasiswa kemungkinan dikarenakan siswa dan mahasiswa lebih banyak menghafal konsep, menggunakan penyederhanaan konsep, dan tidak memperhatikan multiple representasi, khususnya representasi submikroskopik pada soal. Siswa menengah kelas XI paling banyak mengalami miskonsepsi pada subkonsep kekuatan asam dan kekuatan basa dengan kode M7 dan persentase 47,50\%. Siswa menengah atas kelas XII, mahasiswa semester II, dan IV paling banyak mengalami miskonsepsi pada sub-konsep $\mathrm{pH}$ asam dan $\mathrm{pH}$ basa dengan kode $\mathrm{M} 7 \mathrm{dan}$ persentase secara berurutan adalah67,37\%; 53,81\%; 38,57\%.

Pada penelitian ini hanya dikaji mengenai identifikasi miskonsepsi asam basa pada lintas jenjang pendidikan sehingga perlu dikembangkan dalam penelitian mereduksi miskonsepsi asam basa pada masing-masing jenjang pendidikan. Penelitian ini menunjukkan bahwa siswa dan mahasiswa sering mengalami miskonsepsi pada soal-soal yang melibatkan representasi submikroskopik sehingga perlu dilakukan penelitian penerapan model pembelajaran yang dapat meningkatkan kemampuan submikroskopik pada siswa dan mahasiswa.

\section{DAFTAR RUJUKAN}

Amry, U. W., \& Rahayu, S. (2017). Amry, U. W., Rahayu, S., \& Yahmin, Y. (2017). Analisis Miskonsepsi Asam Basa pada Pembelajaran Konvensional dan Dual Situated Learning Model (DSLM). 385-391.

Artdej, R., Ratanaroutai, T., Coll, R. K., \& Thongpanchang, T. (2010). Thai Grade 11 students' alternative conceptions for acidbase chemistry. Research in Science and Technological Education, 28(2), 167-183. https://doi.org/10.1080/02635141003748382.

Chandrasegaran, A. L., Treagust, D. F., \& Mocerino, M. (2007). Thr Develovment of Two-Tier Multiple-Chois Instrument for Evaluating Secondary School Students' Ability to Describe and Explain Chemical Reaction Using Multivel Levels of Refresentation. 8(3), 293-307.

Cetingul, Ipek; geban, O. (2011). using Conceptual Change Texts with Analogies for Misconceptions in Acids and Bases. Hacettepe University Journal of Education, 41, 112-123.

Bretz, S. L., \& McClary, L. (2015). Students' Understandings of Acid Strength: How Meaningful is Reliability when Measuring Alternative Conceptions? Journal of Chemical Education, 92(2), 212-219. https://doi.org/10.1021/ed5005195.

Demircioğlu, G., Ayas, A., \& Demircioğlu, H. (2005). Conceptual Change Achieved through a New Teaching Program on Acids and Bases. Chemistry Education Research and Practice, 6(1), 36-51. https://doi.org/10.1039/B4RP90003K

Dhindsa, H. S., \& Treagust, D. F. (2012). Conceptual Understanding of Bruneian Tertiary Students: Chemical Bonding and Structure. Brunei International Journal of Science \& Mathematic Education, 1(1), 33-51.

Gkitzia, V., Salta, K., \& Tzougraki, C. (2011). Development and Application of Suitable Criteria for the Evaluation of Chemical Representations in School Textbooks. Chemistry Education Research and Practice, 12(1), 5-14. https://doi.org/10.1039/c1rp90003j.

Hasan, S., Bagayoko, D., \& Kelley, E. L. (1999). Misconceptions and the Certainty of Response Index (CRI). Physics Education, 34(5), 294-299. https://doi.org/10.1088/0031-9120/34/5/304.

Hakim, A., Liliasari, \& Kadarohman, A. (2012). Student Concept Understanding of Natural Products Chemistry in Primary and Secondary Metabolites Using the Data Collecting Technique of Modified CRI. International Online Journal of Educational Sciences, 4(3), 544-553.

Head, M. L., Yoder, K., Genton, E., \& Sumperl, J. (2017). A quantitative method to determine preservice chemistry teachers' perceptions of chemical representations. Chemistry Education Research and Practice, 18(4), 825-840. https://doi.org/10.1039/c7rp00109f.

Hoe, K. Y., \& Subramaniam, R. (2016). On the Prevalence of Alternative Conceptions on Acid-Base Chemistry among Secondary Students: Insights from Cognitive and Confidence Measures. Chemistry Education Research and Practice, 17(2), 263-282. https://doi.org/10.1039/c5rp00146c.

Ibda, F. (2015). Perkembangan Kognitif: Teori Jean Piaget. Intelektualita, 3(1), 27-38.

Jannah, M., Ningsih, P., \& Ratman, R. (2017). Analisis Miskonsepsi Siswa Kelas XI SMA Negeri 1 Banawa Tengah pada Pembelajaran Larutan Penyangga dengan CRI (Certainty of Response Index). Jurnal Akademika Kimia, $5(2), 85$. https://doi.org/10.22487/j24775185.2016.v5.i2.8019.

Li, W. S. S., \& Arshad, M. Y. (2014). Application of Multiple Representation Levels in Redox Reactions among Tenth Grade Chemistry Teachers. Journal of Turkish Science Education, 11(3), 35-52. https://doi.org/10.12973/tused.10117a.

Lin, Y. I., Son, J. Y., \& Rudd, J. A. (2016). Asymmetric Translation Between Multiple Representations in Chemistry. International Journal of Science Education, 38(4), 644-662. https://doi.org/10.1080/09500693.2016.1144945.

Luoga, N. E., Ndunguru, P. A., \& Mkoma, S. L. (2013). Research Article High School Students' Misconceptions about Colligative Properties in Chemistry. Tanzania Journal of Natural and Applied Science, 4(1), 575-581. 
Luxford, C. J., \& Bretz, S. L. (2014). Development of the Bonding Representations Inventory to Identify Student Misconceptions about Covalent and Ionic Bonding Representations. Journal of Chemical Education, 91(3), 312-320. https://doi.org/10.1021/ed400700q.

McClary, L. M., \& Bretz, S. L. (2012). Development and Assessment of a Diagnostic Tool to Identify Organic Chemistry Students' Alternative Conceptions Related to Acid Strength. International Journal of Science Education, 34(15), 2317-2341. https://doi.org/10.1080/09500693.2012.684433

Muchtar \& Herizal. (2012). Analyzing of Students Misconceptions on Salt Hydrolysis Chemsitry at Senior High Schools in Padangsidempuan, 3(15), 65-74.

Nyachwaya, J. M., \& Wood, N. B. (2014). Evaluation of Chemical Representations in Physical Chemistry Textbooks. Chemistry Education Research and Practice, 15(4), 720-728. https://doi.org/10.1039/c4rp00113c.

Ozmen, H. (2004). Some Student Misconceptions in Chemistry: Journal of Science Education and Technology, 13(2), $147-159$.

Pan, H., \& Henriques, L. (2015). Students' Alternate Conceptions on Acids and Bases. School Science and Mathematics, 115(5), 237-243. https://doi.org/10.1111/ssm.12124.

Pinarbasi, T. (2007). Turkish Undergraduate Students' Misconceptions on Acid and Bases. Journal of Baltic Science Education, $6(1), 23-34$.

Potgieter, M., Rogan, J. M., \& Howie, S. (2005). Chemical Concepts Inventory of Grade 12 Learners and up Foundation Year Students. African Journal of Research in Mathematics, Science and Technology Education, 9(2), 121-134. https://doi.org/10.1080/10288457.2005.10740583

Sugiyarto, Al. H. P. (2013). Miskonsepsi Atas Konsep Asam-Basa, Kesetimbangan Kimia, dan Redoks dalam Berbagai BukuAjar Kimia SMA/MA. Jurnal Pendidikan Matematika dan Sains, 1(1), 41-53.

Romine, W. L., Todd, A. N., \& Clark, T. B. (2016). How Do Undergraduate Students Conceptualize Acid-Base Chemistry? Measurement of a Concept Progression. Science Education, 100(6), 1150-1183. https://doi.org/10.1002/sce.21240.

Sheppard, K. (2006). High School Students' Understanding of Titrations and Related Acid-Base Phenomena. Chemistry Education Research and Practice, 7(1), 32-45. https://doi.org/10.1039/B5RP90014J.

Sunyono. (2015). Model Pembelajaran Multipel Representasi. Bandar Lampung: Media Akademia.

Suwarto. (2013). Pengembangan Tes Diagnostik dalam Pembelajaran. Yogyakarta: Pustaka Pelajar.

Tümay, H. (2016). Emergence, Learning Difficulties, and Misconceptions in Chemistry Undergraduate Students' Conceptualizations of Acid Strength. Science and Education, 25(1-2), 21-46. https://doi.org/10.1007/s11191-0159799-x.

Wan, Y. J. (Clemson U. (2014). Assessing College Students' Understanding of Acid Base Chemistry Concepts.

Widarti, H. R., Permanasari, A., \& Mulyani, S. (2017). Undergraduate Students' Misconception on Acid-Base and Argentometric Titrations: A Challenge to Implement Multiple Representation Learning Model with Cognitive Dissonance Strategy. International Journal of Education, 9(2), 105. https://doi.org/10.17509/ije.v9i2.5464.

Yalçin, F. A. (2011). Investigation of the Change of Science Teacher Candidates' Misconceptions of Acids-Bases with respect to Grade Level. Journal of Turkish Science Education, 8(3), 173-175. 